\title{
Farmers preferences, uncertainties and opportunities in fruit-tree cultivation in Northeast Luzon
}

\author{
D. J. Snelder · M. Klein · S. H. G. Schuren
}

Received: 26 May 2005/ Accepted: 22 June 2007/Published online: 16 July 2007

(C) Springer Science+Business Media B.V. 2007

\begin{abstract}
The world production of tropical fruit was estimated at about $65 \mathrm{Mt}$ in 2002, of which developing countries accounted for $98 \%$. Although most commercial fruit tree crops are cultivated by largescale commercial enterprises, smallholder fruit-tree cultivation receives much attention in projects aimed at rural development, conservation farming and agroforestry in developing countries. In the Philippines, the integration of fruit trees in smallholder upland farming systems has been promoted since the 1970s. The aim of this paper is to investigate farmers' views on small-scale fruit-tree cultivation based on fieldwork conducted in three upland villages of Northeast Luzon. The factors influencing farmers' preferences are explored and the costs and benefits of fruit tree cultivation compared with those for seasonal cash crops over a 10-year period. Markets for fruit-tree products are identified, at both local and supra-local levels, and risks, uncertainties and opportunities associated with fruit-tree cultivation are discussed. Despite extensive promotion, the adoption of fruit trees in farming systems has occurred at a relatively low pace. In contrast, the cultivation of seasonal cash crops, particularly high-yielding rice and corn varieties, spread rapidly in the 1970s and
\end{abstract}

D. J. Snelder $(\bowtie) \cdot$ M. Klein · S. H. G. Schuren Department of Environment and Development, Institute of Environmental Sciences, Leiden University, P.O. Box 9518, Leiden 2300 RA, The Netherlands e-mail: snelder@cml.leidenuniv.nl 1980s. These crops are planted in monocultures with high inputs of fertilizers and pesticides. Farmers consider fruit trees as a subordinate crop much less profitable than seasonal cash crops, which is in stark contrast with the results of economic analyses of a 10-year production cycle. The Net Present Value (NPV) for citrus (Citrus reticulate) cultivation is at least two times the NPV for irrigated rice and as much as four times the NPV for corn, even at discount rates up to $20 \%$. Farmers' knowledge of tree management and species selection proved to be inadequate, contributing indirectly to low growth rates and fruit production. Marketing opportunities are not fully utilised as evident from unstable network channels for fruit-tree sales, lack of expertise in fruit-tree marketing and insufficient knowledge on market demands, quality production and market location.

Keywords Philippines - Smallholder farmers · Upland farming systems - Tree planting .

Cost-benefits

\section{Introduction}

Most of the recent growth in tropical fruit trade is due to the expansion of plantation areas, agronomic improvements and the development of new varieties for export (FAO 2003a). The so-called major fruits like mango (Mangifera indica), papaya (Carica 
papaya), and avocado (Persea americana) are predominantly produced by large-scale, commercial enterprises throughout Southeast Asia and elsewhere in the tropics. Minor fruits, such as lychees (Litchi chinensis), rambutan (Nephelium lappaceum) and durian (Durio zibethinus) are traded mostly at the regional level and in smaller volumes than the major tropical fruits. The world production of tropical fruit was estimated at about 65 million tonnes in 2002, of which developing countries account for some $98 \%$ (FAO 2003a). It is expected that the world production of tropical fruits will continue to grow, with Asia and the Pacific as the major producing regions accounting for slightly more than $56 \%$ of the global fruit production by 2010 (FAO 2003b). Traditional patterns of fruit consumption are gradually changing, with the consumers in North America and Europe becoming more familiar with tropical fruit including the minor fruits. Moreover, the demand for tropical fresh fruits will also increase with growing human populations and purchasing power, particularly in the developing countries where tropical fruits are produced and consumption is generally highest.

Traditionally, fruit-tree cropping has been practised by smallholders for household consumption in, for example, homegardens and forest gardens (e.g., Kumar and Nair 2004; Wiersum 2004), yet, over the years small-scale fruit production for marketing purposes has gained field. With the transition from shifting agriculture to short-fallow and permanent systems of crop cultivation, more attention has been given to the development of sustainable farming systems to combat decreasing soil productivity, and land degradation in general. Fruit-, fuel- and foddertree crops have been widely introduced as a way to re-establish a protective tree cover in environmentally fragile areas (e.g., Arnold and Dewees 1999; Pimentel and Wightman 1999) and restore the soil fertility status. Likewise, they have been promoted within the framework of rural development programs as an alternative source of livelihood and income diversification, securing a greater degree of self sufficiency. Withrow-Robinson et al. (1999) report on the introduction and distribution of fruit-tree crops in northern Thai Highlands, leading to the adoption of fruit-based agroforestry systems not only among the villagers in project areas but also elsewhere. Examples of spontaneous on-farm tree planting are also presented in the literature. Scherr (1995 in Arnold and Dewees 1999) refers to farmers in western Kenya who cultivate a growing number of tree species on cropland under conditions of increasing land pressure but rising local markets for tree products and seedlings. However, there are also reports on farmers facing limitations in their attempt to extend fruit-tree cropping for commercial purposes. In the highlands of Java, for example, intercropping systems based on apples (Malus domestica) are converted into monoculture apple orchards as a result of tenure and market pressures (Suryanata 1994) whereas the adoption of commercial fruit-tree planting by hill farmers in northern Laos was hindered due to market and infrastructure limitations (Roder et al. 1995). Pattanayak et al. (2003) investigated the factors influencing agroforestry adoption behaviour among smallholders, based on 32 studies primarily from tropical areas. Although preferences and resource endowments were most often included as control factors in these studies, market incentives, risk and uncertainty, and biophysical factors were analysed as the most significant variables affecting adoption behaviour. Franzel et al. (2004), discussing key elements for the scaling up of agroforestry innovations, also stress the importance of local capacity building and the establishment of an enabling policy environment and strategic partnerships.

\section{Fruit tree cultivation in the Philippines}

In addition to Thailand, Indonesia and Malaysia, the Philippines is characterised as one of the major fruitproducing countries of Southeast Asia. Primary fruits for export include coconut (Cocos nucifera), banana (Musa sp.), mango, papaya and guava (Psidium guajava). These fruits and associated products accounted for at least US\$ 874 million, i.e., 58\% of the total value of agricultural products, exported in the year 2000 (FAOSTAT 2004). Yet citrus species, although grown throughout the Philippines, contribute little to the economic value of exported agricultural goods. On the contrary, substantial quantities of citrus fruits and juices have to be imported to supply the demands throughout the Philippines.

The Department of Environment and Natural Resources (DENR) and the Department of Agriculture (DA) have encouraged the integration of fruit trees in upland farming systems through various programs in social forestry and high-value crops 
respectively since the 1970s. Fruit trees, particularly coconut, banana, mango and citrus, are promoted as cash crops in commercial orchards, as intercrop in upland and agroforestry farms and, to a lesser extent, as subsistence crop in the traditional homegardens. Reference is made to its benefits in terms of sustainable livelihood, income diversification and spread of labour. The contribution of trees to soil and water conservation has been advertised through the Sloping Agricultural Land Technology (SALT), i.e., a simple low-cost method of conservation upland farming developed for small farmers with few tools and little capital. The technology is based on the alley cropping system in which corn or upland rice is grown between contoured rows of forage tree legumes and fruit trees; the latter as part of the socalled Small Agrofruit Livelihood Technology or SALT-4 (Watson 1995). Although a 10-year economic study of a farm in Mindanao showed that the application of the SALT technology can at least triple farmers' net annual income (from PhP 4,595 to PhP 15,981 /ha/year), many upland farmers in the Philippines fail to adopt the SALT technology (Laquihon and Pagbilao 1998).

The adoption of technologies incorporating fruit trees in other types of smallholder farming systems has likewise occurred at relatively low pace. In contrast the adoption of seasonal cash crops, particularly the high-yielding rice and corn varieties introduced in the 1970s and 1980s, spread rapidly throughout NE Luzon and elsewhere in the Philippines (Van den Top 2003). Interventions aimed at the development of fruit-tree resources have been hampered by the lack of information about why farmers do or do not grow fruit trees. They may have been based on false assumptions, i.e., counteracting farmers' perception of different fruit trees and their role in meeting needs and production objectives. Moreover, farmers' preferences for fruit-tree cultivation may vary depending on farm accessibility and the distance to local or regional markets. There is still a gap in knowledge of tree cultivation and management practices and the constraints farmers face that limit their potential to develop fruit tree resources within their farms.

The aim of this paper is to investigate and discuss farmers' views on the cultivation of fruit trees for commercial purposes, its constraints and potentials, and describe present fruit-marketing conditions and future sale opportunities based on fieldwork conducted in three upland villages differing in travel time to the nearest regional market, in Northeast Luzon. The factors influencing farmers' motivation to plant fruit trees are investigated, and the costs and benefits of fruit tree cultivation are compared to those of timber trees and seasonal cash crops. Marketing channels of fruit-tree products are identified, and opportunities for facilitating fruit production explored.

\section{Methodology}

This paper is based on a field study conducted in 2003 at three sites in the hilly uplands located at the foot of the Sierra Madre Mountain Range in Northeast Luzon. In the sections below, firstly a description of the hilly upland area is given then the study sites are discussed followed by an overview of the data collection.

The hilly uplands at the foot of the Sierra Madre Mountains

The area is located between 50 m.a.s.l. and 450 m.a.s.l. and borders in eastern direction to the Northern Sierra Madre Natural Park Reserve, i.e., 1 of the 10 protected areas in the Philippines under the National Integrated Protected Areas Systems (NIPAS) Act (DENR/UNEP 1997). The climate is classified as seasonally humid rain forest $\left(\mathrm{A}_{\mathrm{m}}\right.$ of the Köppen system), with a growing season of $7-$ 8 months and a short dry season starting in December and ending in April (mean annual rainfall: 1,5002,500 $\mathrm{mm}$ ). Typhoons cross the area regularly, mostly at the onset of the rainy season in May or towards the end in October and November. One-third of the 20 tropical cyclones traversing the Philippines on average each year go across Northeast Luzon with maximum wind speeds of $65-290 \mathrm{~km} / \mathrm{h}$ and maximum 24-h rainfall of 140-818 mm (PAGASA 2001). Soils are of moderate to, locally, low fertility and can be classified as Cambisols, Luvisols, Planosols and, locally, Ferralsols (Snelder 2001). They are developed over different types of sedimentary rock (i.e., mainly Miocene and Pliocene marine sediments of the Lubuagan, Cabagan and Ilagan Formations; Bureau of Mines and Geo-Sciences 1982; Snelder 
2001). Locally Lithosols occur at sites where plutonic rock reaches the surface (i.e., Batong Labang, the study sited named after "coloured spotted stones").

The uplands are inhabited by heterogeneous communities of forest migrants who migrated towards the Sierra Madre region for various reasons, including the prospect of unoccupied prime agricultural land in the 1950s and early 1960s, the employment in various logging companies in the late 1960s, the 1970s and the 1980s and the limited livelihood opportunities in their places of origin in the 1990s (Van den Top 2003). Whereas the early settlers mainly practiced subsistence-oriented kaingin farming (slash-and-burn agriculture with 2-3 years of crop cultivation and fallow periods of 8 years or more), today farmers are increasingly engaged in market-oriented (semi-) permanent corn cultivation locally diversified with banana on steeper slopes and irrigated, upland or rainfed rice (Oryza sativa) on valley bottoms. Farming activities are unevenly distributed over the year, with labour-peak periods in the wet season. Both rice and corn (Zea mays) provide farmers with produce and cash income once or twice a year (in August and December), whereas banana yields fruits all year round and thus supplies income throughout the year. Virtually all farmers grow fruit, timber or fuelwood trees in their home gardens in addition to the seasonal cash crops planted either in combination with or without trees in the fields outside the villages.

\section{Study sites}

Santa Cruz, Batong Labang and San José, all located in the province of Isabela, are the three villages selected in this study. The criteria for site selection included (1) accessibility and (2) distance to market. The first village, Santa Cruz (Placard) established in the 1940s has 864 inhabitants. It is located along the national highway connecting to three major regional markets, i.e., in order of importance, San Mariano, Ilagan and Cauayan, and a local market, Benito Soliven. All markets can be reached by car, the nearest within less than $1 \mathrm{~h}$. The surrounding terrain is moderately rolling and used as grassland and for intensive corn-based agriculture. Farms vary in size from 1 ha to 6 ha and are mainly privately owned. Batong Labang, the second village, counts 2,893 inhabitants. Most of its inhabitants arrived during the operation time of a logging company up to 1992. The village is located along a river in the Sierra Madre foot hills and is reasonably well accessible by road: $1 \mathrm{~h}$ drive by jeep from the village to the national highway leading to the major market in Ilagan. Farms vary in size from 1 ha up to 6 ha and are either privately owned, leased from the government for at least 25 years or squatted. The farms close to the village are corn-based and market-oriented whereas those further away, on steep sloping land, are kaingin-based and subsistence-oriented. The third village, San José, has more than 1,645 inhabitants. The first settlers arrived in this village in the mid-50s followed by settlers in the mid-60s when the first logging company started its operations in the area. The village is also located in the foot-hill area but closer to the forest fringe and at greater distance from the national highway compared to Batong Labang. Moreover, the dirt road leading to the highway crosses various streams that make the road inaccessible during part of the rainy season. This village is characterised by larger-sized farms on average ( $>2$ ha and up to $8 \mathrm{ha}$ ), most of which are leased from the government for at least 25 years. Yet, part of the farms is left idle because farmers lack time and capital to cultivate all land. The main cash crops grown are corn and banana, and more remote areas are also used for kaingin farming.

\section{Data collection}

A total of 60 farmers have been selected at random for structured interviews in the three villages during a 5-month period in 2003. They all grew trees at least in their home gardens, as is generally practiced throughout the study area. Gmelina (Gmelina arborea) growers were also interviewed in late 2004 and early 2005 to gather additional data on timber yields and profits. During interviews, data were gathered on fruit-tree cultivation schemes, management practices, fruit yields, labour and other costs and benefits, and farmers' preferences, constraints and perception towards fruit-tree cultivation. In addition, field observations were made to study management and cultivation practices. The data on fruit marketing and opportunities for fruit production were collected by interviewing wholesalers, middlemen, and money lenders. Observations on fruit prices were made at local and regional markets. Secondary data on regional fruit tree promotion programs, cultivation 
practices and fruit yields were gathered from government institutions (Department of Agriculture, Department of Environment and Natural Resources, National Statistics Office), non-government organisations (PLAN Philippines, Payoga organic farming) and local farmers' cooperatives.

\section{Fruit-tree cultivation at the study sites}

Whereas farmers use various ways of incorporating fruit trees in their farming systems, the following techniques are most frequently encountered at the study sites: the planting of fruit trees in home gardens, on edges and steep field sections, on field boundaries and as wind breaks, as intercrop of seasonal cash crops like corn and various types of vegetables, and in orchards or large tree plantations in either monocultures or mixed species combinations.

Virtually all farmers grow fruit trees for household consumption in their home gardens. Yet the fruit trees for commercial purposes are grown at different sites, inside and outside the villages, and have partly been promoted by non-governmental organizations or are purely farmers' initiatives. In San José, most fruit trees, i.e., mango, citrus (Citrus sp.) and coconut, are planted as intercrop on corn fields. The planting of fruit trees is partly associated with the Socialized Industrial Forest Management Agreements (SIFMA's), signed in 1998 between at least 55 farmers and the Department of Environment and Natural Resources or DENR (General 2005). The agreements are aimed at agroforestry and forest plantation development, and the equitable access and sharing of rights to natural resources development and utilization. They provide farmers with land tenure security over a period of at least 25 years on the condition that the requirements, such as the planting of trees on leased lots, are met (More recently, in August 2004, the rules and regulations governing the Socialized Industrial Forest Management Program have been revised by the DENR Administrative Order DAO30-2004: forest tree species should be planted in not less than 60\%-in stead of $90 \%$ before-of the land area, fruit trees in not less than $30 \%$ of the area, and the remaining $10 \%$ should be devoted to agricultural crops, preferably perennials; Forest Management Bureau 2004). The farmers received also support from PLAN International, an international NGO conducting a special livelihood and conservation project promoting, amongst others, the SALT technology within the region between 1997 and 2002 (PLAN International 1997, unpublished).

In Batong Labang, most fruit trees are planted in the mixed home-garden fields within the village but some species (mainly mango and citrus) are also planted in monocultures, in orchards outside the village. As opposed to San José, only few farmers in Batong Labang received support from outside; they participated in a pilot project on sustainable agriculture implemented by PLAN International.

In Santa Cruz, fruit trees are planted at a small scale along field boundaries, e.g., mango, coconut, citrus, papaya, guava and at a larger scale on fields up to one hectare (mainly monocultures of mango and citrus). Fruit tree plantation has been promoted by a local NGO, applying the SALT technology within the framework of its organic farming programme launched in 1994.

\section{Marketing of fruit trees}

In San José and Santa Cruz respectively 65\% and 95\% of the farmers grow fruit trees for marketing purposes keeping a small part of the yield for family consumption (Fig. 1). In Batong Labang the situation is the reverse: despite its favourable location in terms of accessibility and distance to the main markets, most farmers (95\%) plant fruit trees primarily for home consumption, yet, any surplus is sold at local markets. Unlike San José, only few farmers received external support in fruit-tree planting activities. Moreover, farmers lack a marketing network like the farmers in Santa Cruz (as discussed below) who have been engaged in tree-cropping over past decades and built up an extensive network with fruit traders throughout the region. The majority of the farmers in Batong Labang still believes in the logging business rather than the fruit-tree enterprise as major source of income, even after the logging ban in 1992. Unlike San José or Santa Cruz, the village benefits from its location along a river used for the transport of logs out of the forested watershed.

The farmers in Santa Cruz enjoy multiple options to sell their fruits. Local selling is practiced for small amounts of fruits. For larger fruit sales, most farmers prefer self transportation to the regional markets (mainly Cauayan located at $40 \mathrm{~km}$ distance, but also 
Fig. 1 Relative share of farmers' fruit production for home consumption and local and regional markets, as estimated for the three villages in Northeast Luzon, Philippines $(n=60)$

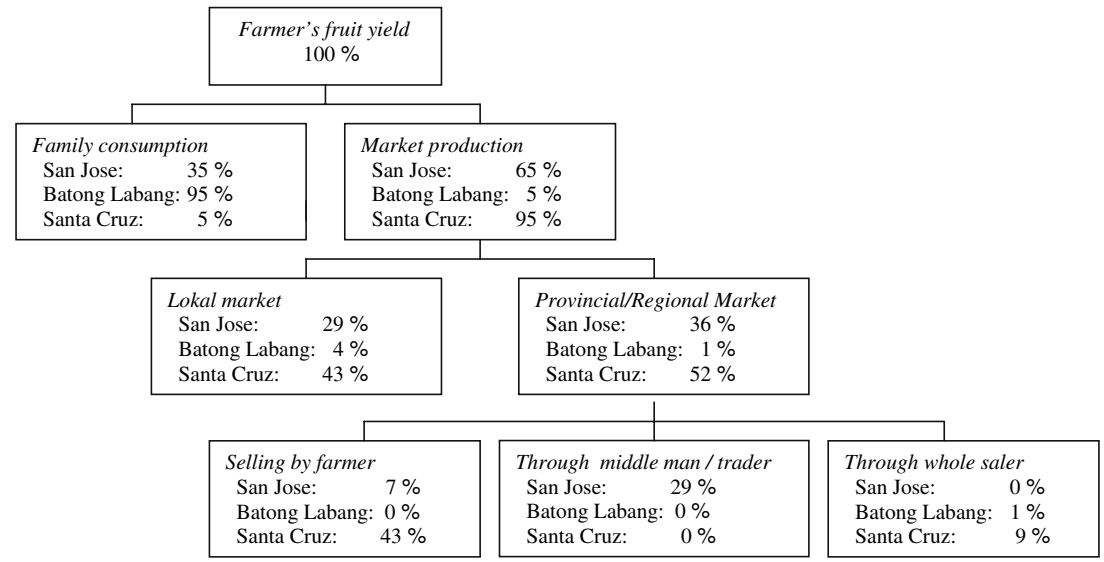

Ilagan and Santiago at 35 and $100 \mathrm{~km}$ distance respectively; all tarmac roads). Farmers can also sell their fruits to the wholesale buyers passing their village. However, this option yields less profit compared to self transportation and the selling of fruits to the regular wholesaler or retailer at the regional markets. Self retailing is also practised if farmers disagree with the prices offered by the regular wholesaler or retailer. The farmers in Santa Cruz are relatively powerful in price negotiations given the range of marketing options available to them, making the farmers less dependent from a single trader and wholesaler.

The wholesalers buy the fruits from the farmers in villages or at local public markets at relatively low prices (yet the prices are still higher than those offered by a middleman) and bring these by truck to major markets elsewhere, within the region (Santiago, Cauayan, Roxas and Ilagan) and further away e.g., Pangasinan, Tarlac and Nueva Ecija up to the markets in Manila, where prices are higher. They operate alone (single whole sale) or in small groups (small collective whole sale). The latter consists of 520 small whole salers who are active at various markets and other places and bring the fruits to one central point from where they organize transport to a large retailer at a major market. The fruit retailers are usually vendors in permanent stores; but also squatter vendors in public markets are present.

The farmers in San José sell their fruits either locally or to a middleman in the village who works for a wholesaler in town and brings the fruits to the nearest market in San Mariano (at $25 \mathrm{~km}$ distance from village; mostly dirt road). Unlike the farmers in
Santa Cruz, the farmers in San José refrain from selling on one of the major markets themselves, given their lack of knowledge about fruit-marketing possibilities, the long travel distance and the poor transportation facilities. They are dependent on the middlemen in the village (eight in total) who, benefiting from farmers' ignorance and lack of other marketing options, offers relatively low prices for the fruit-tree products. The middlemen are, however, mainly engaged in the trade of seasonal crops, most of the fruit trees still being unproductive (they were planted 5-7 years ago). They provide inputs and credits to farmers for the cultivation of corn and rice at interest rates varying between $20 \%$ and $35 \%$. Previous attempts to set up a farmers' cooperative granting credits, farm inputs and trade facilities failed due to (financial) mismanagement. For the farmers in Batong Labang, the opportunities for selling fruits are most limited. There are no fruit traders or middleman in the village. Yet, a few large, often absentee, orchard owners (usually former village heads, overseas workers, or government officials) have sale contracts with wholesalers in Ilagan (located at $45 \mathrm{~km}$ distance from village; mostly tarmac road).

Some of the fruits produced in Northeast Luzon and elsewhere are being used for export to Australia, Japan, Singapore, Indonesia and New Zealand. The most common species used for export include mango, orange and mandarin whereas there is also potential for avocado and rambutan. The quality requirements for export fruit is, however, high (e.g., large-sized mango's without black marks for the Japanese markets). For the average smallholder farmer, it is hard to satisfy the fruit quality conditions mainly 
because of lack of finance to organize proper management, transportation and packaging. Fruits for export are mainly grown by the large-scale orchard owners and traded through export companies in Laguna and Manila. None of the fruit producers in the villages are connected to one of these companies, failing to produce the high-quality fruits for export purposes.

\section{Economic considerations of tree versus seasonal crops}

Whereas the high-yielding rice and hybrid corn varieties spread rapidly throughout the region after their introduction in the 1970s and mid 1980s respectively, this is not true for fruit tree species like citrus and mango that have been promoted by government and non-governmental agencies since the introduction of agroforestry technologies in the 1980s. The only trees species widely adopted by the farmers in their farming systems is the fast-growing timber tree called gmelina (Gmelina arborea). In order to find explanations for these observations, an attempt has been made to make crude estimations of the production costs and the potential profitability of the two common commercial, seasonal crops, i.e., irrigated hybrid rice (Burdagul variety) and hybrid yellow corn (818 Cargil), and compare these results with those for the two most common commercial fruit tree species, i.e., mandarin (Citrus reticulate) and mango (Mangifera indica) and the most common timber tree (Gmelina arborea), over a period of 10 years (Tables 1 and 2). Farmer-based data on annual cost and returns over a cropping cycle of 10 years were used to compute the Net Present Value (NPV) at a range of discount rates $(5 \%, 10 \%, 15 \%$ and 20\%). Discounting, adjusting for the social opportunity cost of capital and for the higher valuation of present costs or benefits compared to future costs and benefits especially among capitalconstrained smallholders, is an issue that raises discussion among social and natural resource scientists. Discount rates tend to be based on formal and informal interest rates in order to adjust for opportunity cost of capital. Since smallholders typically have small time horizons, i.e. highly prefer current benefits over future benefits, the social discount rates for cropping systems to be adopted by capitalconstrained farmers tend to be high. It may be clear from this that discount rates vary among farmers and are difficult to pinpoint exactly. For this reason a range of discount rates has been chosen for the analysis, ranging from rates close to formal interest rates $(5 \%)$, to rates reflecting higher informal credit conditions and high social discount rates (20\%). The calculations are further made for 3 different combinations of input and environmental conditions affecting crop yields: high input and satisfying environmental conditions (no regular occurrence of environmental calamities, such as, drought, flooding, typhoons, pests and diseases), high input and disappointing environmental conditions (i.e., regular occurrence of environmental calamities) and low input and satisfying environmental conditions. In order to assess the impact of price fluctuations on profitability a sensitivity analysis was executed.

The NPV is computed as follows:

$\mathrm{NPV}=\sum_{t=0}^{T} \frac{(B t-C t)}{(1+r)^{t}}$

in which $\sum$ is the sum of the NPVs of the total crop rotation, i.e. 10 years $(T=10), \mathrm{B}$ are the benefits at year $t$ (market value of yield at year $t$ ), $\mathrm{C}$ are the costs at year $t$ (market value of inputs, labour wages, fertilizers, etc. at year $t), t$ is the time in years and $r$ is the discount rate.

The data to determine the net return for the different cropping systems were gathered from interviews with farmers $\left(\mathrm{n}_{\text {corn }}=\mathrm{n}_{\text {rice }}=30, \mathrm{n}_{\text {mango }}=40\right.$, $\mathrm{n}_{\text {mandarin }}=30$ and $\mathrm{n}_{\text {gmelina }}=16$ ). The yield data for gmelina were derived from secondary sources (Lingan 1978; Soerianegara and Lemmens 1993) because consistent field data proved difficult to obtain because of large variations among trees within 10-year old plantations. Whereas all monetary investments are included in the analysis, land opportunity costs are not included. The labour costs refer to hired labour. Family labour is valued at current prices for hired agricultural labour. The main assumptions underlying this cost-benefit analysis are: (a) calculations do not include risks and environmental costs and benefits; (b) inputs are borrowed from a money-lender at a rate of 25\% per cropping (rice and corn) and $25 \%$ per year (trees) and not accumulated (no interest on interest). 
Table 1 Estimated production and marketing costs $\left(\mathrm{PhP} \mathrm{ha}^{-1}\right)$ for a 10-year production period and for different cropping systems in Northeast Luzon, Philippines

\begin{tabular}{|c|c|c|c|c|c|c|}
\hline \multirow[t]{2}{*}{ Costs } & \multicolumn{2}{|l|}{ Seasonal crops ${ }^{\mathrm{a}}$} & \multicolumn{4}{|l|}{ Tree crops } \\
\hline & Yellow corn & Irrigated rice & Mandarin $^{\mathrm{b}}$ & Mango $^{\mathrm{b}}$ & Gmelina $\mathrm{A}^{\mathrm{c}}$ & Gmelina $\mathrm{B}^{\mathrm{c}}$ \\
\hline Labour $^{\mathrm{d}}$ & $100,000(5,000)$ & $100,000(5,000)$ & 113,000 & 86,313 & 51,200 & 5,020 \\
\hline Seeds & $50,000(2,500)$ & $50,000(2,500)$ & - & - & - & - \\
\hline Seedlings & - & - & 13,850 & 2,850 & 5,000 & $1,250^{\mathrm{e}}$ \\
\hline Fertilizer $^{\mathrm{f}}$ & $120,000(6,000)$ & $80,000(4,000)$ & 18,160 & 28,280 & 1,000 & - \\
\hline Pesticides/insect./herbic. & $20,000(1,000)$ & $20,000(1,000)$ & 36,250 & 52,750 & - & - \\
\hline Materials $^{\mathrm{g}}$ & - & - & 12,500 & 37,090 & 10,175 & 4,311 \\
\hline Interest & $72,500(3,625)$ & $62,500(3,125)$ & 48,440 & 51,820 & 16,844 & 2,645 \\
\hline Transportation $^{\mathrm{h}}$ & $40,000(2,000)$ & $40,000(2,000)$ & - & - & - & - \\
\hline Total costs high input ${ }^{\mathrm{i}}$ & 402,500 & 352,500 & 242,200 & 259,104 & 84,219 & - \\
\hline Total costs low input ${ }^{\mathrm{i}}$ & 255,250 & 236,250 & 194,775 & 186,916 & - & 13,226 \\
\hline
\end{tabular}

1 Euro $= \pm 62 \mathrm{PhP}$ in 2003 and $\pm 72 \mathrm{PhP}$ in 2005; $1 \mathrm{US} \$= \pm 55 \mathrm{PhP}$ between 2003 and 2005

a The costs per cropping cycle are also listed for seasonal crops; these are represented by the values in between brackets

${ }^{\mathrm{b}}$ Plant spacing is $6 \times 6 \mathrm{~m}$ for mandarin and $16 \times 16 \mathrm{~m}$ for mango; mandarin starts bearing fruit in 4 th year after planting and mango in 5 th or 6 th year

c The gmelina (Gmelina arborea) A scenario represents a more capital-intensive production system with relatively high investments and the gmelina B scenario a production system with relatively low capital investment and plant spacing ranging from $2 \times 2 \mathrm{~m}$ to $3 \times 4 \mathrm{~m}$

${ }^{\mathrm{d}}$ Hired labour is valued at $100 \mathrm{PhP}$ day $^{-1}$. In the case of gmelina, labour includes the costs of harvesting, i.e. hiring a chainsaw operator, chainsaw and provision of gasoline

e These costs solely refer to the purchase of polypropyleen bags for propagation purposes; the seedlings used in smallholder gmelina plantations are usually not purchased but obtained through self-propagation

${ }^{\mathrm{f}}$ Fertilizers are commonly applied to yellow corn (600 kg ha ${ }^{-1}$ per cropping), rice (400 $\mathrm{kg} \mathrm{ha}^{-1}$ per cropping), mandarin and mango (amounts differ per year) while in the case of gmelina only small amounts are applied during the plantation establishment-phase

$\mathrm{g}$ This includes materials for fencing, and equipment for maintenance and harvesting

${ }^{\mathrm{h}}$ For common marketing schemes, transport arrangements are as follows: self-transportation to buyer for rice and corn, but farm-gate pick up for mandarin, mango and gmelina

i Total costs under high input level includes all inputs listed whereas total costs under low input level is based on applications of fertilizers, pesticides and herbicides to all crops and purchase of certified seeds (or purchase of cheap, poor quality seed) for seasonal crops being conducted only once every 4 years resulting in an estimated $40 \%$ decrease in yields (based on farmers' yield records) and similar reduction in transportation costs

Source: Authors' calculations based on field data

Since, for all crops specific cultivation and marketing systems are in use, the most common arrangements have been chosen as basis for this analysis. This implies that in the case of seasonal crops, farmers arrange and pay harvesting and transportation, while in the case of the perennial production systems, transportation is paid by the buyers. Crop prices correspond to these marketing arrangements. All other costs are based on actual spending by farmers in Philippine Peso $(\mathrm{PhP})$, recalculated on a per hectare basis.
Production costs, benefits and profits

Some general remarks on the costs and profitability of fruit and timber tree cultivation can be made. Significant investments have to be made during the first years of cultivation in order to successfully establish mandarin and mango plantations. These costs amount to about $\mathrm{PhP} 83,200$ in the first 3 years of mandarin plantation and about $\mathrm{PhP} 76,700$ in the first 4 years of mango plantation. The costs are counterbalanced by a gradual increase of profits over 
Table 2 Comparison of estimated costs, benefits, profits and $\mathrm{NPV}\left(\mathrm{PhP} \mathrm{ha}{ }^{-1}\right)$ at average crop prices for different cropping systems under different input and environmental conditions, and consequently yield levels, based on a 10-year production cycle in Northeast Luzon, Philippines

\begin{tabular}{|c|c|c|c|c|c|}
\hline & \multicolumn{2}{|c|}{ Seasonal crops } & \multicolumn{3}{|l|}{ Tree crops } \\
\hline & Yellow corn & Irrigated rice & Mandarin & Mango & Gmelina A or B \\
\hline \multicolumn{6}{|c|}{ High input and satisfying environmental conditions } \\
\hline Total costs & 402,500 & 352,500 & 242,200 & 259,104 & 84,219 \\
\hline Total production & $84,000 \mathrm{~kg}^{\mathrm{a}}$ & $75,000 \mathrm{~kg}^{\mathrm{a}}$ & $122,157 \mathrm{~kg}$ & $38,760 \mathrm{~kg}$ & $80.54 \mathrm{~m}^{3}$ \\
\hline Total benefits & 546,000 & 600,000 & $1,465,884$ & 581,400 & 409,800 \\
\hline Total profit & 143,500 & 247,500 & $1,223,684$ & 322,296 & 325,581 \\
\hline NPV at $5 \%$ discount rate & 110,807 & 191,113 & 793,482 & 194,953 & 179,175 \\
\hline NPV at $10 \%$ discount rate & 88,175 & 152,078 & 522,348 & 115,591 & 94,193 \\
\hline NPV at $15 \%$ discount rate & 72,019 & 124,215 & 347,338 & 65,142 & 44,016 \\
\hline NPV at $20 \%$ discount rate & 60,162 & 103,674 & 231,936 & 32,543 & 14,019 \\
\hline \multicolumn{6}{|c|}{ High input and disappointing environmental conditions ${ }^{\mathrm{b}}$} \\
\hline Total costs & 402,500 & 352,500 & 242,200 & 259,104 & 84,219 \\
\hline Total production & $50,400 \mathrm{~kg}$ & $45,000 \mathrm{~kg}$ & $73,294 \mathrm{~kg}$ & $23,256 \mathrm{~kg}$ & $48.32 \mathrm{~m}^{3}$ \\
\hline Total benefits & 327,600 & 360,000 & 879,530 & 348,840 & 245,860 \\
\hline Total profit & $-74,900$ & 7,500 & 637,330 & 89,735 & 161,641 \\
\hline NPV at $5 \%$ discount rate & $-57,836$ & 5,791 & 399,966 & 39,022 & 70,728 \\
\hline NPV at $10 \%$ discount rate & $-46,023$ & 4,608 & 251,613 & 8,511 & 18,227 \\
\hline NPV at $15 \%$ discount rate & $-37,591$ & 3,764 & 156,815 & $-10,004$ & $-12,461$ \\
\hline NPV at $20 \%$ discount rate & $-31,402$ & 3,144 & 95,062 & $-21,245$ & $-30,475$ \\
\hline \multicolumn{6}{|c|}{ Low input and satisfying environmental conditions ${ }^{\mathrm{b}}$} \\
\hline Total costs & 255,250 & 236,250 & 194,775 & 186,916 & 13,226 \\
\hline Total production & $50,400 \mathrm{~kg}$ & $45,000 \mathrm{~kg}$ & $73,294 \mathrm{~kg}$ & $23,256 \mathrm{~kg}$ & $48.32 \mathrm{~m}^{3}$ \\
\hline Total benefits & 327,600 & 360,000 & 879,530 & 348,840 & 245,860 \\
\hline Total profit & 72,350 & 123,750 & 684,755 & 161,924 & 232,634 \\
\hline NPV at $5 \%$ discount rate & 55,515 & 94,691 & 434,829 & 89,572 & 138,340 \\
\hline NPV at $10 \%$ discount rate & 43,751 & 74,551 & 277,967 & 44,889 & 82,766 \\
\hline NPV at $15 \%$ discount rate & 35,251 & 60,152 & 177,238 & 16,836 & 49,272 \\
\hline NPV at $20 \%$ discount rate & 28,928 & 49,567 & 111,244 & -984 & 28,686 \\
\hline
\end{tabular}

1 Euro $= \pm 62 \mathrm{PhP}$ in 2003 and $\pm 72 \mathrm{PhP}$ in 2005; $1 \mathrm{US} \$= \pm 55 \mathrm{PhP}$ between 2003 and 2005

a Yields for corn typically range from 40 to 110 cavans per hectare per cropping and for irrigated rice from 50 to 120 cavans per hectare per season $(1$ cavan $=50 \mathrm{~kg}$ ); farmers strive to have two croppings per year although during dry years, or in case of lack of funds, farmers plant in one season only; provincial records on yields for 2005 correspond to $3,175 \mathrm{~kg}$ per hectare for yellow corn and $4,293 \mathrm{~kg}$ per hectare for irrigated rice (Bureau of Agricultural Statistics 2006); in this table, the average yield-calculated from field data-is used and based on croppings per year

b Assumption is made that yields generated under high input and poor environmental conditions or yields under low input and regular environmental conditions are $40 \%$ below those generated under optimal input and environmental conditions

Source: Authors' calculations all—except the Gmelina yield data (see text)—based on field data

the years, resulting in a positive balance after the third or fourth year of fruit production, i.e., respectively 6 and 7 years after planting mandarin and mango. Gmelina plantation establishment requires also sizeable investment and coverage of maintenance costs for weeding and pruning, yet the costs are lower compared to those for mandarin and mango. Seedlings are often obtained through self propagation whereas the application of fertilizers is generally limited to the establishment phase. Plant spacings vary in the field but relatively close spacings of $2 \times 2 \mathrm{~m}$ up to $3 \times 4 \mathrm{~m}$ are generally practiced in order 
to generate straight stems. The spacings observed in the field correspond to those recommended for gmelina by the DENR (2005). Other sources (e.g., Center for New Crops and Plants Products 2005) refer to a spacing of $2 \times 2 \mathrm{~m}$ for gmelina fuelwood plantations and somewhat wider spacings for gmelina timber plantations. For reasons of data availability, it is assumed that all gmelina will be sold in one sale at the age of 10, although actual harvesting practices tend to differ. Rather than being harvested all at once, gmelina trees are mostly harvested multiple times from the sixth and seventh year onwards based on tree growth, sales opportunities, producers' cash needs and climatic conditions (typhoon). Therefore the NPV for gmelina production may be on the conservative side. Similarly, the NPV for mango production would increase when a longer crop rotation would be taken, since the most productive years of mango production are generally reached after 15 years. Lastly, the total costs for seasonal crops may be slightly underestimated, with the annual fertilizer inputs being set at equal rates over a period of 10 years whereas one may assume that these inputs slightly increase over the years, given a decrease in soil fertility as reported by the farmers in the field.

The comparison of the Net Present Value (NPV) of the different crops at average prices shows that fruit tree cultivation compares favourably to seasonal cropping at low discount rates, for all the three input and environmental conditions (Table 2). If environmental conditions are satisfying, irrigated rice production (based on two yields per year) compares favourably to mango and gmelina production except for mango produced at a high input level and a 5\% discount rate and for gmelina produced at low input level and a discount rate of either $5 \%$ or $10 \%$. However, yellow corn tends to be less profitable than all tree plantation systems at discount rates of 5-10\% and if the input level is low, it becomes only slightly more profitable than gmelina at a discount rate of $20 \%$ (Only at a discount rate of $12 \%$ and higher, yellow corn becomes more profitable than gmelina and at a rate of $14 \%$ and higher it is more profitable than mango as well). The cultivation of mandarin seems a very promising undertaking, yielding at least more than two times as much as rice and about 4 times as much as yellow corn, even at a high discount rate. However because markets for rice and yellow corn are well established, i.e. producers experience little difficulty in selling their produce, and moneylenders for seasonal crops (as opposed to those for tree crops) are easy to find, seasonal crops may be preferred over tree crops the markets of which are just developing.

Farmers experience, however, high losses when cultivating seasonal crops under high input levels but environmental conditions turning out disappointing. The losses for corn cultivation are highest at all discount rates, whereas the benefits derived from irrigated rice are lower than those derived from all the tree plantations at discount rates of $5 \%$ and $10 \%$. Mandarin still yields considerable benefits in all cases whereas mango and gmelina plantations only result in losses at higher discount rates (i.e., $15 \%$ or $20 \%)$.

Sensitivity analysis

In developing countries, the prices for agricultural crops and commodities generally vary greatly within and between seasons. Hence, in order to assess the impact of possible price fluctuations on marginal profitability, a sensitivity analysis was performed (Table 3). The analysis demonstrates that tree farming becomes more attractive (particularly compared to corn at $15 \%$ discount rate) if current prices for seasonal crops decrease and environmental conditions are satisfying, whereas if prices increase, the profitability of tree crops (mango and gmelina) becomes less favourably especially compared to yellow corn at $10 \%$ and $15 \%$ discount rates. If environmental conditions are disappointing, losses occur and these are most pronounced for corn whether prices increase or decrease. If prices decrease, also irrigated rice suffers from severe losses whereas the tree plantations still yield some benefits at lower discount rates.

The sensitivity analysis further shows that mandarin is the most profitable tree crop, for each price scenario. In addition, given a $15 \%$ discount rate and an average price for yellow corn, a $4 \%$ increase in mango price is needed in order to make this fruit tree competitive with yellow corn. For gmelina, this requires a price increase of $28 \%$ given the same conditions. These observations are of great importance to the farmers and tree growers in Northeast Luzon since yellow corn in particular tends to compete with tree crops in terms of land use. 
Table 3 Sensitivity of NPV (in PhP ha ${ }^{-1}$ ) of different crops, cultivated under different input and environmental conditions, to price fluctuations for various discount rates in Northeast Luzon, Philippines

\begin{tabular}{|c|c|c|c|c|c|c|}
\hline \multirow{2}{*}{$\begin{array}{l}\text { Price fluctuation ( } \% \text { above or below } \\
\text { average price) }\end{array}$} & \multirow[t]{2}{*}{ Discount rate $(\%)$} & \multicolumn{2}{|c|}{ Seasonal crops } & \multicolumn{3}{|l|}{ Tree crops } \\
\hline & & Yellow corn & Irrigated rice & Mandarin & Mango & $\begin{array}{l}\text { Gmelina } \\
\text { A or B }\end{array}$ \\
\hline \multicolumn{7}{|c|}{ High input and regular environmental conditions } \\
\hline \multirow[t]{5}{*}{+15} & 0 & 225,400 & 337,500 & $1,443,567$ & 409,505 & 387,150 \\
\hline & 5 & 174,048 & 260,609 & 941,050 & 253,426 & 216,973 \\
\hline & 10 & 138,499 & 207,379 & 623,873 & 155,746 & 117,931 \\
\hline & 15 & 113,123 & 169,383 & 418,784 & 93,322 & 59,234 \\
\hline & 20 & 94,498 & 141,496 & 283,264 & 52,714 & 23,963 \\
\hline \multirow[t]{5}{*}{-15} & 0 & 61,600 & 157,500 & $1,003,801$ & 235,085 & 264,210 \\
\hline & 5 & 47,566 & 121,617 & 645,913 & 136,479 & 141,499 \\
\hline & 10 & 37,851 & 96,777 & 420,822 & 75,437 & 70,532 \\
\hline & 15 & 30,916 & 79,046 & 275,892 & 36,963 & 28,846 \\
\hline & 20 & 25,826 & 66,031 & 180,608 & 12,373 & 4,107 \\
\hline \multicolumn{7}{|c|}{ High input and poor environmental conditions } \\
\hline \multirow[t]{5}{*}{+15} & 0 & $-25,760$ & 61,500 & 769,260 & 142,061 & 198,520 \\
\hline & 5 & $-19,891$ & 47,489 & 488,507 & 74,107 & 101,171 \\
\hline & 10 & $-15,828$ & 37,789 & 312,528 & 32,604 & 45,206 \\
\hline & 15 & $-12,928$ & 30,865 & 199,683 & 6,904 & 12,608 \\
\hline & 20 & $-10,800$ & 25,784 & 125,859 & $-9,142$ & $-6,502$ \\
\hline \multirow[t]{5}{*}{-15} & 0 & $-124,040$ & $-46,500$ & 505,401 & 37,409 & 124,762 \\
\hline & 5 & $-95,780$ & $-35,906$ & 311,425 & 3,938 & 55,890 \\
\hline & 10 & $-76,217$ & $-28,572$ & 190,697 & $-15,581$ & 16,769 \\
\hline & 15 & $-62,253$ & $-23,337$ & 113,947 & $-26,912$ & $-5,624$ \\
\hline & 20 & $-52,003$ & $-19,495$ & 64,265 & $-33,347$ & $-18,415$ \\
\hline \multicolumn{7}{|c|}{ Low input and regular environmental conditions } \\
\hline \multirow[t]{5}{*}{+15} & 0 & 121,490 & 177,750 & 816,685 & 214,250 & 269,513 \\
\hline & 5 & 93,460 & 136,389 & 523,371 & 124,657 & 162,370 \\
\hline & 10 & 73,945 & 107,731 & 338,882 & 68,982 & 99,171 \\
\hline & 15 & 59,913 & 87,253 & 220,106 & 33,744 & 61,027 \\
\hline & 20 & 49,530 & 72,207 & 142,041 & 11,118 & 37,532 \\
\hline \multirow[t]{5}{*}{-15} & 0 & 42,210 & 69,750 & 552,909 & 109,598 & 195,755 \\
\hline & 5 & 31,074 & 52,994 & 346,345 & 54,488 & 117,089 \\
\hline & 10 & 23,306 & 41,370 & 217,103 & 20,796 & 70,734 \\
\hline & 15 & 17,732 & 33,051 & 134,412 & -72 & 42,795 \\
\hline & 20 & 13,629 & 26,928 & 80,481 & $-13,086$ & 25,619 \\
\hline
\end{tabular}

1 Euro $= \pm 62 \mathrm{PhP}$ in 2003 and $\pm 72 \mathrm{PhP}$ in 2005; $1 \mathrm{US} \$= \pm 55 \mathrm{PhP}$ between 2003 and 2005

Source: Authors' calculations based on field data

The integration of fruit trees in farming systems: farmers' preferences

Assuming farmers only plant fruit trees if the operation will be profitable, farmers' perception of profitability is the more interesting. Farmers were asked what they believe is more profitable in 10 years time, the cultivation of fruit trees or the cultivation of seasonal crops like corn and rice: $58 \%$ of all farmers answered that seasonal crops are more profitable in 
economic terms, even over a period of 10 years. In addition $67 \%$ of the total number of farmers does not prefer fruit trees above seasonal crops, regardless farmers' awareness of the higher, long-term benefits.

Farmers prove to be even more uniform in their preference for specific types of trees: at least $90 \%$ of the farmers prefer to cultivate fruit trees rather than timber trees (Table 4). Fruit tree establishment is considered as a long-term and sustainable way of investment. Once the trees bear fruits, they provide the farmers with a regular flow of cash income for many years without reinvestment. Timber tree plantations require reinvestment in seedlings after harvesting and need a growing period of at least 7 years in case of fast-growing species, such as, Gmelina arborea during which no income can be obtained from timber production. Moreover, farmers refer to the low market price for fast-growing timber trees. Other arguments for preferring fruit trees above timber trees are the continuous need for food like fruits as opposed to the irregular need for timber or construction material.

In San José, $30 \%$ of all farmers refer to the realization of SIFMA requirements, when discussing reasons for planting fruit trees aside from marketing and home consumption. Yet other reasons are associated with the trees' multiple functions, including erosion control in hilly farms, delineation of field boundaries, investment for retirement purposes, production of ready-to-eat snacks and creation of shade around a house or in a farm.

Remarkable is that most market-oriented farmers prefer small-scale fruit-tree enterprises aimed at quality rather than quantity production (Table 4). Good quality fruit is needed for the market, yet, the production of good quality fruit requires proper maintenance and care of trees, including rather costly and labour-intensive operations such as regular pruning and pesticide control. Farmers having no or limited capital at their disposal are generally unable to set up large-scale plantations. An exception are a few farmers using "gradual plantation establishment" as main tree planting strategy, cultivating-for a couple of years-part of their land with seasonal commercial crops to generate cash for seedling purchase and other required inputs. Most farmers, however, prefer short-term yielding crops (e.g., vegetables, corn, rice) rather than long-term yielding fruit trees (e.g., citrus, mango), even if the former result in less profit. This preference arises from farmers' need for short-term cash income or necessity to economize on food. When planting fruit trees, farmers preferably practise intercropping with seasonal crops such as corn and vegetables. This is particularly true for the first couple of years after planting when trees do not yield any food and income yet. Even when trees are fully grown, farmers prefer to cultivate seasonal crops in tree plantations to prevent weed growth, generate more harvest per hectare, and control soil degradation. However, there is field evidence that the seasonal crops in intercropping systems suffer from the competition with trees for nutrients and water. They perform less well and give lower yields compared to mono-cropping systems, as stated by the farmers in this study.

Table 4 Farmer's preferences towards integrating fruit trees in farming systems in three villages in the Cagayan Valley, Northeast Luzon

\begin{tabular}{|c|c|c|c|c|c|c|}
\hline Farmer's preferences & \multicolumn{2}{|l|}{ San José } & \multicolumn{2}{|c|}{ Batong Labang } & \multicolumn{2}{|c|}{ Santa Cruz } \\
\hline Total number of households & 232 & & 546 & & 189 & \\
\hline \multirow[t]{2}{*}{ Travel time village - highway to market (hour) } & $>1$ & & 1 & & $<1$ & \\
\hline & $N=20$ & $\%$ & $N=20$ & $\%$ & $N=20$ & $\%$ \\
\hline Prefers fruit trees above timber trees & 19 & 95 & 18 & 90 & 19 & 95 \\
\hline Prefers long-term above short-term yielding crops & 5 & 25 & 5 & 25 & 10 & 50 \\
\hline Prefers quality above quantity fruit production & 6 & 30 & 2 & 10 & 14 & 70 \\
\hline Prefers small-scale above large-scale fruit tree enterprise & 16 & 80 & 18 & 90 & 19 & 95 \\
\hline Prefers fruit tree intercropping ${ }^{\mathrm{a}}$ above monoculture & 18 & 90 & 17 & 85 & 16 & 80 \\
\hline Market production is main reason for planting fruit trees & 13 & 65 & 1 & 5 & 19 & 95 \\
\hline
\end{tabular}

a Intercropping of fruit trees with seasonal crops such as corn and vegetables 
Species preference and fruit tree yield

Farmers select fruit tree species not only on the basis of their economical value but also on the basis of other important functions that trees may provide. The fruit trees encountered at the study sites are categorized below based on the main functions as identified by farmers:

- cash sellers: trees providing high quality, highpriced fruits, e.g., mango (carabao or native variety), citrus, coconut, papaya, avocado, rambutan (Nephelium lappaceum), guyabano (Anonna muricata), lansones

- family fruit providers: trees mainly planted for household consumption (primarily food but also medicine) e.g., mango (Indian variety), jackfruit (Artocarpus heterophyllus), starapple (Chrysophyllum canito), coconut, santol (Sandoricum koetjape), kalamansi (Citrus microcarpa)

- all-year-round producers: trees providing produce and cash income throughout the year like coconut (i.e., the main all-year-round producer besides banana), breadfruit (Artocarpus altilis) and papaya, as opposed to the main seasonal producers of citrus fruits and mango

- producers of fruit with good keeping qualities or qualities facilitating transport: trees producing fruits that can be stored for some time or that have a resistant, protective skin such as coconut and citrus species, as opposed to those that should be consumed or processed soon after harvesting or have a thin, sensitive skin such as mango, papaya and avocado

- erosion controllers: "strong" trees with extensive root systems or organic matter inputs to bind soil and minimize erosion on steep slopes, e.g., starapple, mango (Indian variety), jackfruit, pummelo (Citrus maxima), santol

- wind breakers: trees resistant to typhoons or protecting field crops from heavy wind, e.g., coconut, mango, pummelo

- multipurpose trees: coconut and kalamansi and various fruit trees often planted near the house to provide, in addition to fruits, shade (e.g., mango, avocado)

The top three fruit species preferred by the farmers in this study are, in order of importance, mango, coconut, and citrus (kalamansi and mandarin or $C$. reticulata). Mango and mandarin are preferred species because of their high yields and economic returns and their strong growth. Coconut is a multipurpose tree providing farmers with various types of products for both utilizing at home and selling at the market, including fruit for consumption, leaves for roof construction, fibre for gardening, coconut shell for production of various utensils, and wood for timber and flooring. Farmers further mention that coconut is free from diseases, grows well without fertilizers and, in contrast to mango and citrus, it is resistant to heavy wind. Likewise, kalamansi is a favorite fruit tree because of its multipurpose use. Its fruits are nutritious, used for flavouring, and have medicinal value. Moreover, the tree bears fruit after 3 years already. The fruit is sold locally at the market, to shops and sometimes to traders.

The economic value in terms of annual fruit yield for various tree species is presented in Fig. 2a and b, the former showing yield per full-grown tree and the latter yield per 1-ha of full-grown trees for various common fruit tree species. Whereas the economic returns are the highest for mango when based on yield per individual tree, they are the highest for orange (Citrus sinensis) when calculated on the basis of yield per hectare (the average number of trees planted on a 1-ha field is 277 for citrus and 57 for mango). The returns for mandarine and particularly kalamansi are considerably lower, yet, farmers prefer these species above orange. They clarify that local biophysical conditions are less favourable for orange cultivation (due to the spread of citrus greening, a highly destructive disease caused by the bacterium Candidatus Liberobacter spp. and transmitted by the Asiatic citrus psyllid or Diaphorina citri Kuwayama).

Farmers' reasons for not preferring fruit trees above seasonal crops

The results on farmers' perception of fruit-tree profitability are in strong contrast with the costbenefit analyses for the seasonal and fruit tree crops discussed earlier. The farmers give various explanations for their negative perception and non-preference for fruit tree cultivation (Table 4). Firstly, the investments for establishing fruit-tree plantations are extremely high and outside reach of the resource-poor farmers. Whereas they can easily 
a)

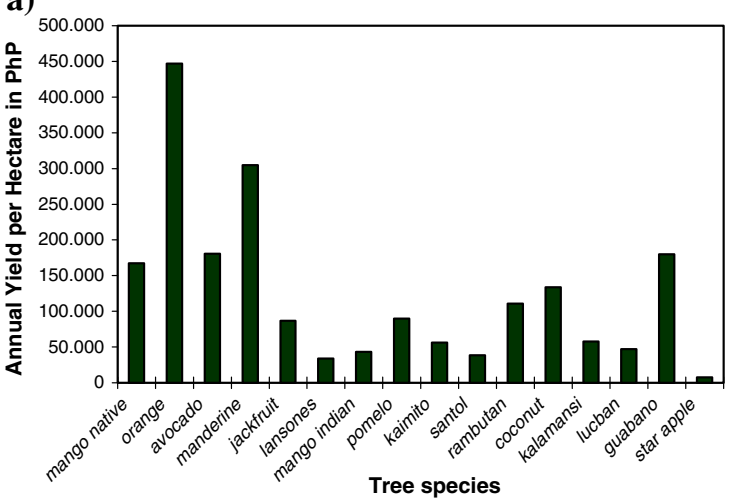

b) 3.500

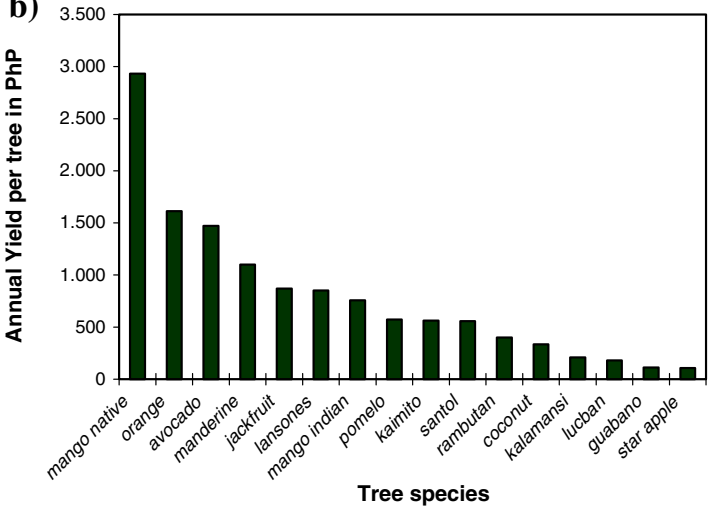

Fig. 2 The economic value (in Philippine Peso; 1 Euro $= \pm 62$ $\mathrm{PhP}$ and $72 \mathrm{PhP}$ in 2003 and 2005 respectively), in terms of (a) estimated annual yield per tree in full production (a) and annual yield per hectare (b) for common fruit tree species in Northeast Luzon, Philippines (mango-carabao or native variety: Mangifera indica L.; orange: Citrus sinensis (L.) Osbeck; avocado: Persea americana L.; mandarin: Citrus reticulata L.; jackfruit: Artocarpus heterophyllus Lam.; lansones: Lansium domesticum Corr.; mango India variety: Mangifera indica L.; pummelo or lucban: Citrus maxima Merr.; kaimito or star apple: Chrysophyllum canito L.; santol: Sandoricum koetjape Merr.; rambutan: Nephelium lappaceum L.; coconut: Cocos nucifera L.; kalamansi: Citrus microcarpa L.; soursop or guyabano: Annona muricata $\mathrm{L}$

obtain a loan from money lenders to cover their input costs associated with the cultivation of rice and corn, this is not true in case of loans for fruit-tree cultivation. The trees will only yield enough income to redeem their loans after 6 or 7 years. This is perceived, by both the money lenders and the farmers themselves, as a too long period and, therefore, a too risky and expensive undertaking to lend money for. In addition the profits, that could be used to redeem loans for investments, are expected to be lower than the estimates in Table 4 because plant growth conditions are rarely optimal and steady over a longer period of time. Income from off-farm activities, particularly financial support from relatives working in cities or abroad, proved to be an essential asset to provide for the much needed capital to establish and maintain a fruit-tree plantation. The long-term investments in large orchards that are mainly in hands of the more well-to-do farmers often serve as farmers' retirement plan, generating income in "old days".

Secondly, fruit tree cultivation preferably serves as a supplementary source of income and relatively long-term investment whereas the seasonal crops generate farmers' main source of cash income requiring low and short-term investment.

Thirdly, farmers further state that they lack experience with fruit-tree cultivation and are more knowledgeable about rice and corn cultivation. Yet unlike the Ilocano's, i.e., the major ethnic group in each of the three villages, the migrants from Mountain Province, Pangasinan and Nueva Viscaya are knowledgeable fruit-tree cultivators who learned about fruit-tree cultivation techniques by tradition.

Fourthly, farmers refer to the fatal effect of major disasters, such as typhoon or fire events, in terms of "instantaneously loss of years of effort". Although fruit trees are less regularly affected by environmental calamities compared to seasonal crops, they also mention that much more time, capital and labour are needed once damage occurs and fruit-tree plantations must be re-established. Yet, some farmers consider the risks commonly associated with seasonal crops, including the high price falls during peak production and the adverse effects of drought, pest and diseases, to have greater cumulative effect over a longer period of time than those commonly associated with fruit tree cultivation, such as, the damages caused by typhoons and fire. One technology used by farmers to combat typhoon damage to mango trees is to partly pull down the trees and leave those that are pushed down by heavy winds on the ground. As time progresses, the trees recover and become stronger by forming new offshoots and extending its root system while remaining at lower height. The reduction in tree height facilitates the picking of fruits and limits the impact of typhoons and heavy winds whereas the increase in offshoots usually improves fruit production. 
Finally the farmers in the more remote villages of San José and Batong Labang express resistance to planting fruit trees at a larger scale because of a lack of stable and reliable marketing channels; this, in contrast to the availability of good marketing channels for rice and corn.

\section{Risks and uncertainties}

When discussing the planting of fruit trees on farm land, farmers refer to a number of risks and uncertainties associated with resource endowment, knowledge and facilitation, market incentives and recurrent typhoon and fire events. In general, insecure land rights withhold farmers from long-term investment in fruit-tree plantations if prospects for increased land or tree security (e.g., through a tree tenure contract associated with the Tree for Legacy Program) are absent. However, land ownership is not necessarily a precondition for fruit tree planting. In fact in the Philippines, land ownership is not a legal option for lands with slopes of $18 \%$ or more (i.e., most land in Batong Labang and San Jose falls in this category) because these lands are government owned and to be reserved for forests and reforestation. The latter refers to plantations of indigenous and exotic forest species and partly also fruit trees. Yet, farmers who do cultivate such lands are either squatters (often in areas where land use conflicts prevail) or owners of a land lease contract (e.g., SIFMA) offering land tenure security for a period of 25 years or more, i.e., an economically feasible period for the establishment of fruit-tree plantations.

Farmers identify both small farm size and poor farm quality as factors associated with risk and influencing their decision not to plant trees on their land. Farmers with private land usually face the division of land among their offspring. This intergenerational transmission leads to smaller-sized farms that farmers preferably reserve for the cultivation of seasonal crops securing themselves with shortterm cash income. The same is true for tenant farmers with small-sized plots. They avail of limited flexibility to deal with the risks of high long-term investments associated with fruit-tree establishment. Moreover, poor farm quality, in terms of accessibility and workability due to steep and rocky slopes, hinder economically feasible fruit-tree production at the more remote sites of San Jose and Batong Labang. These sites, mainly inhabited by migrants who settled down at a later stage (in the 1990s) when most fertile land had already been taken, are mainly characterized by forest and timber trees.

Farmers in Batong Labang further relate to factors constraining the marketing of fruit-tree products, such as, unreliable market channels, poor infrastructure and limited transport facilities. Moreover, their negative expectations about income changes when planting fruit trees on their farm withhold farmers from fruit production for commercial purposes. The establishment of a farmers' cooperative may be one way to facilitate the trade and transport of fruits. However, in San José, farmers' attempts to set up a co-operative failed four times due to financial mismanagement.

Lack of knowledge proves to be another reason why farmers refrain from planting fruit trees or, if they do, face disappointing yields. Field observations in San Jose and Batong Labang made clear that the presence of government and non-governmental programs reduced the risk of tree mortality and poor yield among some farmers who received seedlings for free and had the opportunity to join workshops and training programs about fruit-tree cultivation.

Finally, recurrent damage by typhoons (resulting in heavy wind and flooding) proves to be a major risk in fruit tree production in NE Luzon, yet, farmers found some ways of coping with it.

\section{Conclusions}

This study suggests that trees, particularly gmelina and mandarin, yield more benefits over a 10 year period than corn, for smallholder farmers using low input levels, under reasonable environmental conditions. Such conditions are representative of farmers in far-from-market villages, such as San José in this study, rather than farmers living close to the market where inputs are readily available and returns from tree products are greater. Under conditions of high input, tree plantations are also beneficial, based on the results of this study particularly at low discount rates-but the net present values for corn are higher at discount rates of $15 \%$ or more. Irrigated rice is 
generally more profitable compared to corn, but it cannot compete with mandarin (and when inputs are low also not with gmelina in most cases) in terms of output giving the highest profits under the combinations of input levels and environmental conditions discussed in this paper.

These findings contrast with farmers' perceptions that seasonal crops are more profitable even over a period of 10 years. Although farmers do recognize the advantage of fruit trees like mandarin, kalamansi and mango, providing a regular flow of cash income for many years without reinvestment, they have to address various constraints before deciding to plant trees. Investments are high and long-term, whereas credit facilities are lacking, and in contrast to the marketing channels for rice and corn, the marketing channels for tree crops are still unstable and unreliable particularly in more remote villages like San Jose.

As the demand for fruit-tree products will grow over the next decades, at local, national and international levels, the role of smallholders is likely to increase in importance. Moreover, fruit trees are instrumental in meeting farmer's multiple household objectives, yielding food and other by products, and providing a protective cover in environmentally fragile landscapes. However, farmers' views, preferences and constraints need recognition in the design of policy and technical interventions to facilitate widespread adoption of viable fruit-tree producing operations. Reducing risks and uncertainties and providing or strengthening opportunities for fruit tree production is imperative for achieving increased adoption of tree-based farming systems. Fruit tree plantations with a well-selected set of species may be an outcome, supplying additional produce and income throughout the year. In San José, banana fulfils such a function as an all-year-round supplier of fruit for commercial purposes. The existing marketing channels may offer opportunities for the marketing of fruits other than banana. Yet, market investigations are needed to confirm and identify fruit species demands in these and also other distribution areas. Fruit-producing smallholders may consider concentrating on fruits other than those produced by large-scale commercial enterprises enabling them to enter the market.

An increase in production benefits can be achieved by providing farmers with technologies that facilitate fruit-tree establishment, reduce the risks to tree damage, and improve quality (to meet commercial demand), storage and processing of fruit-tree products. Like farmers' marketing-related technologies, these more technical interventions can be incorporated into farmer training and extension services associated with the policies of agrarian reform, community-based forest management and reforestation, and agro-industrial cropping. Moreover, a more bottom-up approach of establishing a platform for knowledge dissemination and sharing of views and preferences among fruit producers and consumers will assist in filling existing information gaps.

Finally, farmers' lack of capital for long-term investments in plantation establishment, maintenance and technology improvement calls for access to reliable and low-interest credit systems. Whereas currently, farmers can avail of loans for seasonal crops, however, on an informal basis, there are no lending systems at all for tree crops. Support for micro-credit systems are more likely to be developed through government and non-government institutions, given the relatively high risks and low profitability of smallholder enterprises for commercial banks.

Acknowledgements This research has been conducted within the framework of the Cagayan Valley Programme on Environment and Development (CVPED), a joint undertaking of the College of Forestry and Environmental Management (CFEM; Isabela State University, Philippines) and the Institute of Environmental Sciences (CML; Leiden University, Netherlands). The authors like to thank Kees Vermeulen (Hogeschool InHolland), Rutger van Heck and the CVPED staff for their assistance and facilitation.

\section{References}

Arnold JEM, Dewees PA (1999) Trees in managed landscapes: factors in farmer decision making. In: Buck LE, Lassoie JP, Fernandes ECM (eds) Agroforestry in sustainable agricultural systems. CRC Press/Lewis Publishers, Boca Raton, Florida, pp 277-294

Bureau of Mines and Geo-Sciences (1982) Geology and mineral resources of the Philippines, vol 1, Geology, Ministry of Natural Resources, Manila

Center for New Crops \& Plants Products (2005) Gmelina arborea Roxb. Plant list based on the Handbook of Energy Crops by James A. Duke. 1983, compiled by Purdue University, USA. http://www.hort.purdue.edu/newcrop/ duke_energy/Gmelina_arborea.html, Accessed on March 17,2005

Department of Environment and Natural Resources (DENR)/ United Nations Environment Programme (UNEP) (1997) 
Philippine biodiversity: an assessment and action plan. Bookmark, Makity City, Manila, 298 pp

Department of Environment and Natural Resources (DENR) (2005) Forest Management Bureau website. http://forestry.denr.gov.ph/faqs.htm, Accessed on March 17, 2005

FAO (2003a) Current market situation for tropical fruits. Publication of the Committee on Commodity Problems, Intergovernmental Group on Bananas and on Tropical Fruits Meeting 11-15 December 2003. CCP: BA/TF/03/9. ftp://ftp.fao.org/unfao/bodies/ccp/ba-tf/04/j0773e.pdf. 0709-2004 or http://www.fao.org/unfao/bodies/ccp/ba-tf/ 2004/bntf04_en.htm, Accessed September 7, 2004

FAO (2003b) Medium-term projections for world supply and demand to 2010 for tropical fruits. Documents of the Committee on Commodity Problems, Intergovernmental Group on Bananas and on Tropical Fruits Third Session Meeting 11-15 December 2003. CCP: BA/TF/03/10. ftp:// ftp.fao.org/unfao/bodies/ccp/ba-tf/04/j0603e.pdf, http:// www.fao.org/unfao/bodies/ccp/ba-tf/2004/bntf04_en.htm, downloaded on 07-09-2004

FAOSTAT data (2004) http://faostat.fao.org/faostat/collections?subset=agriculture, downloaded on 07-09-2004

Forest Management Bureau (2004) Revised rules and regulations governing the Socialized Industrial Forest Management Program DAOP30-2004. http://forestry.denr.gov.ph/ DAO30-2004.pdf, downloaded on 09-11-2004

Franzel S, Denning GL, Lillesǿ JPB, Mercado AR Jr (2004) Scaling up the impact of agroforestry: lessons from three sites in Africa and Asia. Agrofor Syst 61:329-344

General AA (2005) Co-management of the environment through the socialized integrated industrial forest management agreement (SIFMA): the San Mariano experience. In: Snelder DJ, Bernardo EC (eds) Comanaging in practice: the challenges and complexities of implementation in the Northern Sierra Madre Mountain Region. Ateneo de Manila Press, Manila, Philippines

Kumar BM, Nair PKR (2004) The enigma of tropical homegardens. Agrofor Syst 61:135-152

Laquihon WA, Pagbilao MV (1998) Sloping Agricultural Land Technology (SALT) in the Philippines. In: Gutteridge RC, Shelton HM (eds) Forage tree legumes in tropical agriculture. Tropical Grassland Society of Australia Inc., Queensland

Lingan B (1978) Growth and yield prediction for Yemane pulp timber and sawtimber. Master's thesis, University of the Philippines, Los Banos
PAGASA (2001) Rainfall records Region II 1991-2000. Philippine Atmospheric, Geophysical and Astronomical Services Administration, National Climate Monitoring Center, Manila

Pattanayak SK, Mercer DE, Sills E, Yang J-C (2003) Taking stock of agroforestry adoption studies. Agrofor Syst 57:173-186

Pimental D, Wightman A (1999) Economic and environmental benefits of agroforestry in food and fuelwood production. In: Buck LE, Lassoie JP, Fernandes ECM (eds) Agroforestry in sustainable agricultural systems. CRC Press/ Lewis Publishers, Boca Raton, Florida, pp 294-317

Roder W, Keoboualapha B, Manivanh V (1995) Teak (Tectona grandis), fruit trees and other perennials used by hill farmers of northern Laos. Agrofor Syst 29:47-60

Scherr SA (1995) Tree growing to meet household needs: farmer strategies in western Kenya. In: Arnold JEM, Dewees PA (eds) Tree management in farmer strategies: responses to agricultural intensification. Oxford University Press, Oxford

Snelder DJ (2001) Soil properties of Imperata grasslands and prospects for tree-based farming systems in Northeast Luzon, The Philippines. Agrofor Syst 52(1):27-40

Soerianegara I, Lemmens RHMJ (eds) (1993) Plant resources of South-East Asia (PROSEA) 5 (1) timber trees: major commercial timber. Pudoc Scientific Publishers, Wageningen, The Netherlands

Suryanata K (1994) Fruit trees under contract: tenure and land use change in upland Java, Indonesia. World Dev 22(10):1567-1578

Van den Top GM (2003) The social dynamics of deforestation in the Philippines: actions, options and motivations. NIAS Press, Copenhagen

Watson HR (1995) The development of Sloping Agricultural Land Technology (SALT) in the Philippines. Food and Technology Center: An International Information Center for farmers in the Asia Pacific Region, http:// www.fftc.agnet.org/library/article/eb400a.html, downloaded on 06-09-2004

Wiersum F (2004) Forestgardens as an 'intermediate' land-use system in the nature-culture continuum: characteristics and future potential. Agrofor Syst 61:123-134

Withrow-Robinson B, Hibbs DE, Gypmantasiri P, Thomas D (1999) A preliminary classification of fruit-based agroforestry in a highland area of northern Thailand. Agrofor Syst 42:195-205 